\title{
Elevated Carbon Dioxide Level Suppresses Nutritional Quality of Lettuce and Spinach
}

\author{
Anju Giri, Brenden Armstrong, Channa B. Rajashekar* \\ Department of Horticulture, Forestry and Recreational Resources, Kansas State University, Manhattan, KS, USA \\ Email: "crajashe@ksu.edu
}

Received 10 December 2015; accepted 26 January 2016; published 29 January 2016

Copyright @ 2016 by authors and Scientific Research Publishing Inc.

This work is licensed under the Creative Commons Attribution International License (CC BY).

http://creativecommons.org/licenses/by/4.0/

(c) (i) Open Access

\begin{abstract}
Rising global $\mathrm{CO}_{2}$ levels are a major factor that impacts not only the environment but also many plant functions including growth, productivity and nutritional quality. The study examined the impact of elevated $\left[\mathrm{CO}_{2}\right]$ on nutritional quality and growth characteristics of lettuce (Lactuca sati$v a$ ) and spinach (Spinacia oleracea). Elevated $\left[\mathrm{CO}_{2}\right]$ decreased the concentration of many important nutrients including nitrogen (protein), potassium and phosphorus in the edible parts of both lettuce and spinach. The nitrogen concentration in lettuce shoots was reduced by more than $\mathbf{3 0 \%}$ at elevated $\left[\mathrm{CO}_{2}\right]$ compared to the plants grown at ambient level of $\mathrm{CO}_{2}$. Similarly the concentration of a number of micronutrients including sulfur, zinc, copper and magnesium, was depressed in lettuce shoots. Although the total phenolic content and antioxidant capacity were higher in lettuce at elevated $\mathrm{CO}_{2}$, they were not affected in spinach. The photosynthetic activity was variable among the plant species while there was no increase in the carbon accumulation in these plants at elevated $\left[\mathrm{CO}_{2}\right]$. However, there was significant reduction in the leaf stomatal conductance in both lettuce and spinach in response to higher $\left[\mathrm{CO}_{2}\right]$, which is likely affect both water loss from the leaves and their photosynthetic activity. The results indicate a broad adverse impact of rising $\left[\mathrm{CO}_{2}\right]$ on the nutritional quality of commonly consumed leafy vegetables namely, lettuce and spinach.
\end{abstract}

\section{Keywords}

Elevated Carbon Dioxide, Lettuce, Nutritional Quality, Phytochemicals, Protein Deficiency, Spinach

\section{Introduction}

A major part of our changing environment is the rapid and steady increase in the global atmospheric $\mathrm{CO}_{2}$ concentration $\left(\left[\mathrm{CO}_{2}\right]\right)$ which is predicted to continue to rise to dangerous levels in the coming decades [1]. The ris-

\footnotetext{
*Corresponding author.
}

How to cite this paper: Giri, A., Armstrong, B. and Rajashekar, C.B. (2016) Elevated Carbon Dioxide Level Suppresses Nutritional Quality of Lettuce and Spinach. American Journal of Plant Sciences, 7, 246-258. 
ing $\left[\mathrm{CO}_{2}\right]$ levels affect not only the climate but also directly the crop growth and productivity and thus, the global food security. A number of studies have examined the impact of elevated $\left[\mathrm{CO}_{2}\right]$ on plant growth and production [2] [3]. The consensus appears to be that elevated $\left[\mathrm{CO}_{2}\right]$ is likely to increase the biomass and yield [4]-[7], which is related to an increase photosynthetic rate in plants [8]. However, this increase in photosynthetic activity is short lived and not sustained over a long term exposure to elevated $\mathrm{CO}_{2}$. Such plants tend to acclimate to high levels of $\mathrm{CO}_{2}$ and become less responsive [9]. Another important effect of elevated $\mathrm{CO}_{2}$ is its ability to decrease plants' stomatal conductance thereby reducing their transpiration and improving their water use efficiency leading to improved drought resistance [10] [11]. Thus, these studies indicate that there has been a greater focus on the effect of rising $\mathrm{CO}_{2}$ levels on plant growth, function and productivity; however, very little attention has been given to its possible impact on the nutritional quality of crops. Furthermore, by and large, studies relating nutritional quality remain mostly centered around field crops. Relatively, there are only a few studies dealing with the nutritional quality of fruits and vegetables as affected by elevated $\left[\mathrm{CO}_{2}\right]$ despite their importance in human health. In recent decades, fruits and vegetables are being actively promoted as a significant part of a healthy diet because they are typically rich in nutrients and health-promoting phytochemicals, and thus their daily consumption can not only reduce the risk of chronic and degenerative diseases but also provide a sense of overall well-being [12]-[15].

While the rising $\mathrm{CO}_{2}$ levels are likely to increase the yield of many crops [16] [17], they can also lower their protein content [18]. There is a growing consensus on the negative impact of higher $\left[\mathrm{CO}_{2}\right]$ on the nitrogen accumulation in field crops, however, its impact on the overall nutritional quality reflecting other important nutrients and phytochemicals still remains inconclusive [19]. Recently, in an extensive meta-analysis to examine the effect of elevated $\left[\mathrm{CO}_{2}\right]$ on nutrient content of several varieties of 6 commonly cultivated field crops, Myers et al. [18] showed that major $\mathrm{C}_{3}$ cereal crops including rice and wheat had lower concentration of iron and zinc, in addition to protein, compared to their counter parts grown at ambient $\mathrm{CO}_{2}$ level. Thus, the reduced concentration of these important nutrients in major cereal crops (rice and wheat) and legumes (field peas and soybean) which are the staple crops in many developing countries certainly raises the specter of a wide spread global malnutrition.

Elevated $\left[\mathrm{CO}_{2}\right]$ can also affect the health-promoting phytochemicals in plants which have not been adequately explored. There have been some reports that show that elevated $\mathrm{CO}_{2}$ may increase the photosynthetic activity in plants favoring higher $\mathrm{C}-\mathrm{N}$ ratio which is likely to have a positive impact on the synthesis of secondary metabolites many of which are known to function as health-promoting phytochemicals and plant defense compounds [20]-[23]. In this study, we examine the effect of elevated $\left[\mathrm{CO}_{2}\right]$ on the nutritionally important nutrients, health-promoting phytochemicals and the growth and development of popular leafy vegetables, namely lettuce and spinach.

\section{Materials and Methods}

\subsection{Plant Growing Conditions}

Lactuca sativa (Lettuce, var. Black-Seeded Simpson) and Spinacia oleracea (Spinach, var. Bloomsdale Long Standing) were used as model plants in this study. Seeds (W. Atlee Burpee \& Co., PA) were germinated in flats $\left(11^{\prime \prime} \mathrm{W} \times 21.37 " \mathrm{~L} \times 2.44 " \mathrm{D}\right)$ containing Premier Promix soil medium (Hummert International, KS) in a controlled environmental chamber maintained at $280-300 \mu \mathrm{mol} \cdot \mathrm{m}^{-2} \cdot \mathrm{s}^{-1} \mathrm{PAR}$ (photosynthetically active radiation), 12-hour photoperiod, and $18 / 20^{\circ} \mathrm{C}$ (night/day) temperature with $400 \mathrm{ppm}$ of $\mathrm{CO}_{2}$ (control). After initiation of true leaves, plants were fertilized with 20-10-20 nutrient solution Peters Peat-Lite (Hummert International, KS) at $200 \mathrm{ppm}$ constant liquid feed rate. Plants were watered every other day and fed with fertilizer solution once a week. Each seedling, at 2 - 4 leaf stage, was transplanted to individual pot (4” diameter) containing the same soil mix as indicated above. Plants were grown for 5 days before applying the $\mathrm{CO}_{2}$ treatments. They were transferred to a Conviron $\mathrm{CO}_{2}$ growth chamber (CMP 6050 Control System) set at the same growing conditions as described above but at $700 \mathrm{ppm}$. Plants were randomly assigned to the treatments on a completely randomized design with 12 replications and were moved within each chamber once in two days to minimize the variability of environmental conditions within the growth chambers. Growth chamber temperature was checked periodically to make sure that it was maintained at the desired level. The concentration of $\mathrm{CO}_{2}$ was monitored using an infrared gas analyzer (LiCOR Model 6400, NE). 


\subsection{Macro and Micro Nutrients}

The concentration of each macro- and micro-mineral nutrients was determined using ground dry shoot and root samples. Concentration of phosphorus, potassium, calcium, magnesium, zinc, iron, copper, manganese and sulfur $\left(\mathrm{SO}_{4}\right)$ was determined by perchloric digest method as outlined by Gieseking et al. [24]. The nutrient concentration was quantified from the perchloric digest using an Inductively Coupled Plasma (ICP) Spectrometer (Model 720-ES ICP Optical Emission Spectrometer, Varian Australia Pty Ltd., Australia). Total carbon and nitrogen content (organic and inorganic) in samples was determined using LECO TruSpec carbon/nitrogen combustion analysis (LECO Corp., MI).

\subsection{Total Phenolics}

Total phenolic compounds were extracted according to Oh et al. [20] using a modified Folin Ciocalteu reagent method. One gram of leaf tissue each from 6 replicates (in each treatment) was ground in $6 \mathrm{~mL}$ of $80 \%$ acetone and then $1.5 \mathrm{~mL}$ of the sample was transferred to a centrifuge tube and kept in the darkness overnight at $4^{\circ} \mathrm{C}$. The extract was than centrifuged at $1000 \mathrm{rpm}$ for $5 \mathrm{~min}$ and a $50 \mu \mathrm{L}$ of the supernatant was mixed with $135 \mu \mathrm{L}$ of water, $750 \mu \mathrm{L}$ diluted (1:10) Folin-Ciocalteu reagent (Sigma-Aldrich, St. Louis, MO) and $600 \mu \mathrm{L}$ of 7.5\% (w/v) $\mathrm{Na}_{2} \mathrm{CO}_{3}$. The mixture was vortexed and incubated in water bath at $45^{\circ} \mathrm{C}$ for $15 \mathrm{~min}$ and was then allowed to cool at room temperature. Absorbance was read at $765 \mathrm{~nm}$ (U-1100 spectrophotometer, Hitachi Ltd. Japan). Gallic acid standards were prepared from freshly prepared gallic acid $1 \mathrm{mg} / \mathrm{mL}$ gallic acid (Acros Organics, Belgium) in $80 \%$ acetone with 3 replicates for each concentration.

\subsection{Total Antioxidants}

Total Antioxidants were measured using ABTS decolorization assay as outlined by Miller and Rice-Evans [25] and Pennycooke et al. [26]. A $5 \mathrm{mM}$ ABTS stock solution was prepared in $20 \mathrm{~mL}$ distilled water and the ABTS* radical cations were generated by adding $1 \mathrm{~g}$ of $\mathrm{MnO}_{2}$ as an oxidizing agent to ABTS solution and stirring continuously at room temperature. Excess $\mathrm{MnO}_{2}$ was removed by filtering through a Buchner funnel under vacuum first, and then using $0.2 \mu \mathrm{M}$ syringe end filter. Then the ABTS* solution was diluted to an absorbance value of $0.7( \pm 0.02)$ at $734 \mathrm{~nm}$ by using $5 \mathrm{mM}$ PBS (phosphate buffer saline) at $\mathrm{pH} 7.4$ and stored in a water bath at $30^{\circ} \mathrm{C}$. Trolox standards were prepared from a stock solution of $0.5 \mathrm{mM}$ trolox. One $\mathrm{mL}$ of ABTS* reagent was added to trolox standards or samples and vortexed for $10 \mathrm{~s}$ and followed by $1 \mathrm{~min}$ of reaction time. The absorbance of the reaction mixture was measured at $734 \mathrm{~nm}$. A PBS solution was used as a blank for each assay. The antioxidant capacity of samples was estimated as the mean value of trolox equivalent.

\subsection{Plant Growth Measurements}

Growth performance of plants was monitored by measuring plant height and leaf number after 10 and 17 days of transplanting in lettuce and every week in spinach. Leaf area measurement was conducted immediately after harvesting. The plants were separated into leaves, stem and roots. Out of 12 total replicates, 6 replicate samples were immediately frozen for biochemical analysis and another set of 6 samples was harvested for biomass and to measure leaf area. To measure leaf area, leaves were scanned (4 replicates for lettuce and 6 replicates for spinach) using a scanner (Epson Perfection V700 Scanner, Seiko Epson Corporation, Japan) and analyzed by using an image analysis system, winFOLIA (Regents instruments Inc. Canada). The total biomass of plants was determined by measuring fresh weight followed by dry weight, obtained by drying the samples in an oven for 72 hours at $70^{\circ} \mathrm{C}$. Similarly, shoot and root samples were dried and ground for nutrient content analyses.

\subsection{Photosynthetic Efficiency and Stomatal Conductance}

Steady state net photosynthesis $\left(P_{n}\right)$ and stomatal conductance $\left(g_{s}\right)$ were measured using an infrared gas analyzer (LiCOR, Model 6400, NE) equipped with a $6 \mathrm{~cm}^{2}$ leaf cuvette with controlled environmental conditions $\left(\mathrm{CO}_{2}\right.$, light and temperature). Measurements were made after 2 weeks of treatment in lettuce and after 3 weeks in both lettuce and spinach following the manufacturer's guidelines. Recently fully expanded leaves receiving direct light were used for the study. 


\subsection{Leaf Chlorophyll}

Newly matured leaves $(0.35 \mathrm{~g})$ were ground in $3 \mathrm{~mL}$ of cold acetone in a chilled mortar and pestle in the dark. Samples were centrifuged at $4000 \mathrm{rpm}$ for $10 \mathrm{~min}$ and the supernatant was pipetted into another tube. The pellet was washed 3 times with $3 \mathrm{~mL}$ of cold acetone followed by centrifugation. The extract was combined to make a final volume of $12 \mathrm{~mL}$ and its absorbance was read at $663 \mathrm{~nm}, 646 \mathrm{~nm}, 710 \mathrm{~nm}$ and $652 \mathrm{~nm}$ and $C h l a, b$ and total chlorophyll were determined using the following relationships [27]:

Chl a $(\mathrm{mg} / \mathrm{mL})=12.21\left(\mathrm{~A}_{663}-\mathrm{A}_{710}\right)-2.81\left(\mathrm{~A}_{646}-\mathrm{A}_{710}\right)$

Chl b $(\mathrm{mg} / \mathrm{mL})=20.13\left(\mathrm{~A}_{646}-\mathrm{A}_{710}\right)-5.03\left(\mathrm{~A}_{663}-\mathrm{A}_{710}\right)$

Total Chl $(\mathrm{mg} / \mathrm{mL})=27.8\left(\mathrm{~A}_{652}-\mathrm{A}_{710}\right)$

\subsection{Statistical Analyses}

The experiments were conducted using a completely randomized design with 12 replications and the treatments were separated using student's t-test with $p$-value threshold set at 0.05 . The treatment means with standard error are presented with significant differences indicated at 0.01 or 0.05 level.

\section{Results and Discussion}

Growing lettuce and spinach at elevated $\left[\mathrm{CO}_{2}\right]$ reduced the accumulation of many nutrients important for human nutrition both in their shoots and roots. In edible parts of lettuce (shoots), nitrogen, phosphorus, potassium, sulfur, magnesium, copper and zinc levels were significantly lower at high $\left[\mathrm{CO}_{2}\right]$ compared to ambient $\left[\mathrm{CO}_{2}\right]$ (Figure 1 and Figure 2). The percent changes in the concentrations for the nutrients in shoots and roots due to elevated $\left[\mathrm{CO}_{2}\right]$ in relation to control are presented in Figure 2 and Figure 4 for lettuce and spinach respectively. The concentration

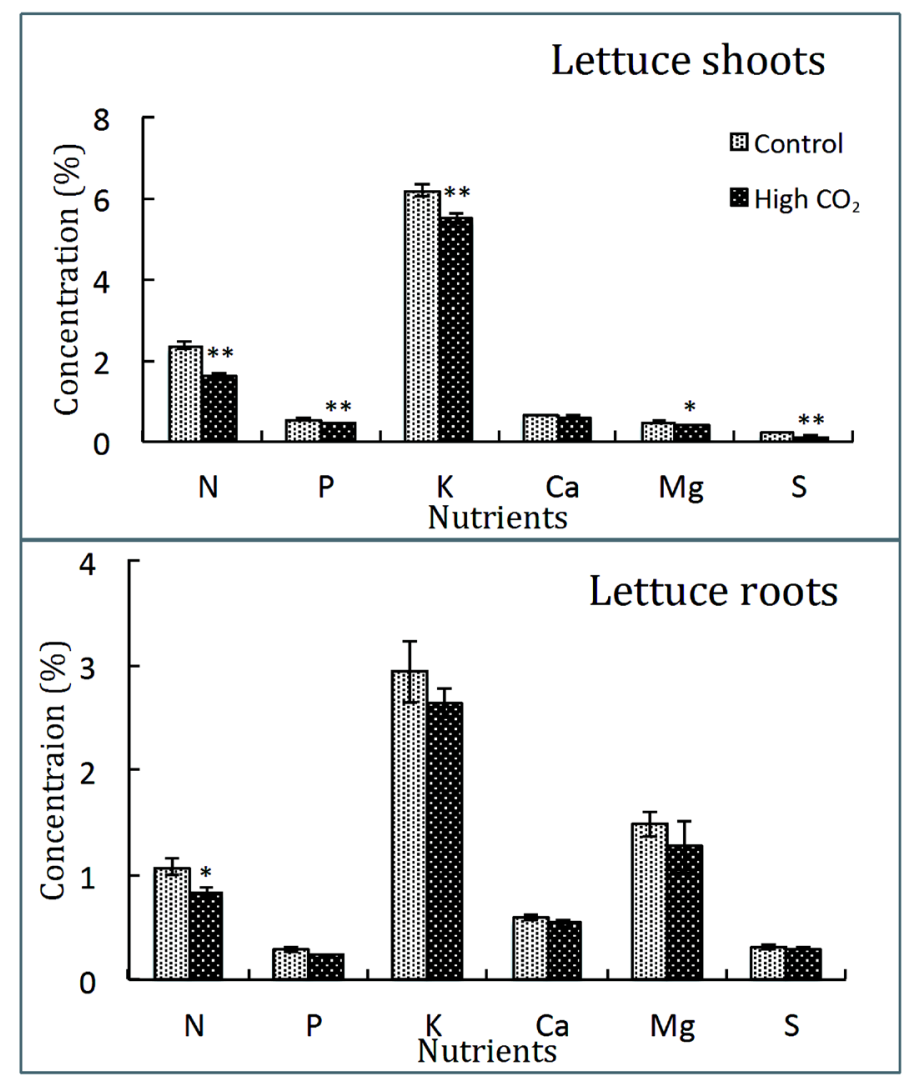

Figure 1. Nutrient concentration in lettuce at plants ambient and elevated $\left[\mathrm{CO}_{2}\right]$. Lettuce plants were grown at ambient (control) and elevated level of $\mathrm{CO}_{2}(700 \mathrm{ppm})$. Levels of major nutrients in shoots and roots were measured after harvest. Means with standard error bars and significant differences at $p<0.05\left(^{*}\right)$ and $p<0.01\left(^{* *}\right)$ are presented. 


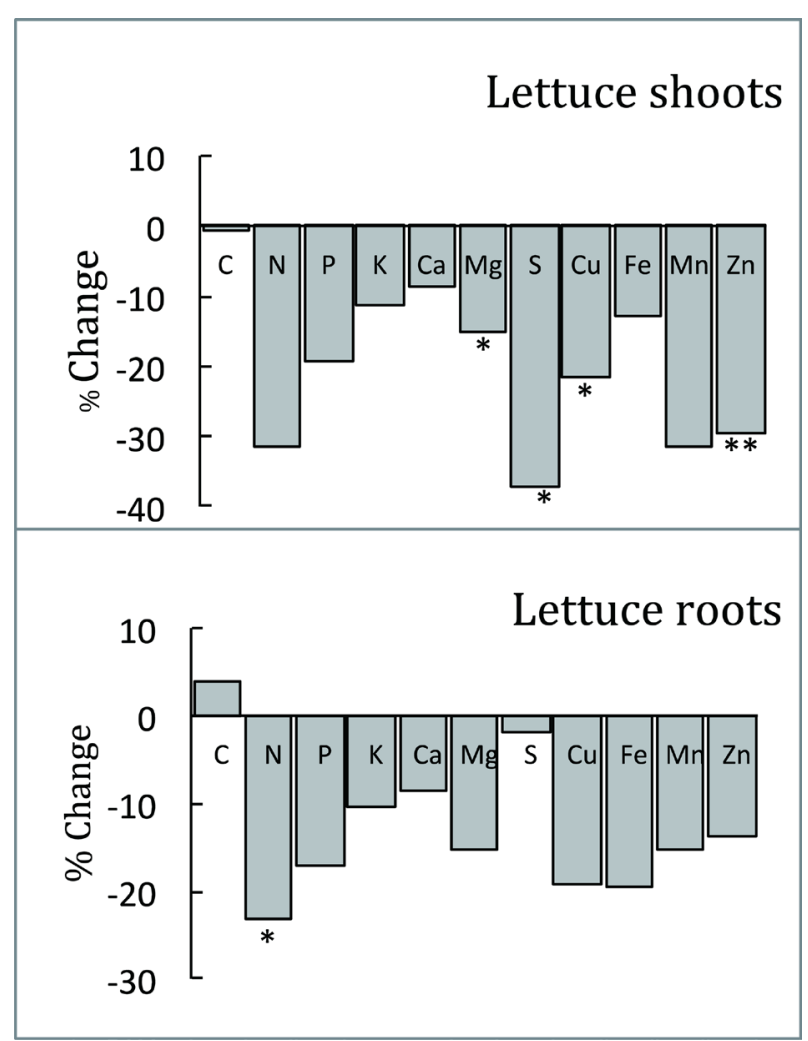

Figure 2. Percent change in nutrient concentrations in lettuce in response to elevated $\left[\mathrm{CO}_{2}\right]$. The changes in the nutrient concentration relative to the controls in shoots and roots of lettuce caused by elevated $\left[\mathrm{CO}_{2}\right]$ are presented. Significant differences are indicated at $p<0.05\left(^{*}\right)$ and $p<0.01\left(^{* *}\right)$.

of nitrogen and sulfur in lettuce shoots was reduced by more than $30 \%$ and that of copper and zinc by more than $20 \%$ relative to the plants grown at ambient $\left[\mathrm{CO}_{2}\right]$ (Figure 2). In spinach shoots, there was also a general decline in the level of macro and micro nutrients important in human diet at elevated $\left[\mathrm{CO}_{2}\right]$. Significant decrease in nitrogen, phosphorus and potassium concentration occurred in the shoots grown at elevated $\left[\mathrm{CO}_{2}\right]$ (Figure 3). Nitrogen concentration in both shoots and roots of lettuce was depressed while it was only lower in spinach shoots but not in roots. The only major nutrient that accumulated at higher concentration at elevated $\left[\mathrm{CO}_{2}\right]$ was calcium in spinach shoots, which was about $17 \%$ higher than in those grown at the ambient $\mathrm{CO}_{2}$ level (Figure 4). However, carbon accumulation in shoots and roots of both lettuce and spinach was not affected by elevated $\left[\mathrm{CO}_{2}\right]$.

There is overwhelming evidence that elevated $\left[\mathrm{CO}_{2}\right]$ can suppress not only protein content but also various other important nutrients in many wide ranging field crops [18]. Reduced protein content in food crops has serious implication especially in developing countries in Africa, Asia and Latin America not only among general population but also among young children where protein deficiency can lead to stunted growth and increased vulnerability to many diseases [28] [29]. In a number of $C_{3}$ cereal and legume crops, Myers et al. [18] found that elevated $\left[\mathrm{CO}_{2}\right]$ under field conditions significantly depressed the level of protein, iron and zinc in the edible portions of these crops. The reason for low protein concentration in these crops could be due to interference of nitrogen (especially nitrate) assimilation by high $\left[\mathrm{CO}_{2}\right]$ [30]. In addition, the general decrease in nutrient content in plants grown at elevated $\left[\mathrm{CO}_{2}\right]$ is often thought to be due to dilution caused by high carbon accumulation [31]. This may not be the case because the decline in individual nutrient concentrations at elevated $\left[\mathrm{CO}_{2}\right]$ is quite variable [18]. For example, in this study elevated $\left[\mathrm{CO}_{2}\right]$ actually increased the calcium concentration in spinach shoots while concentration of other nutrients either decreased or was not affected. Furthermore, it should be noted that in this study elevated $\left[\mathrm{CO}_{2}\right]$ did not have any significant effect on the carbon accumulation in both lettuce and spinach (Figure 2 and Figure 4). 


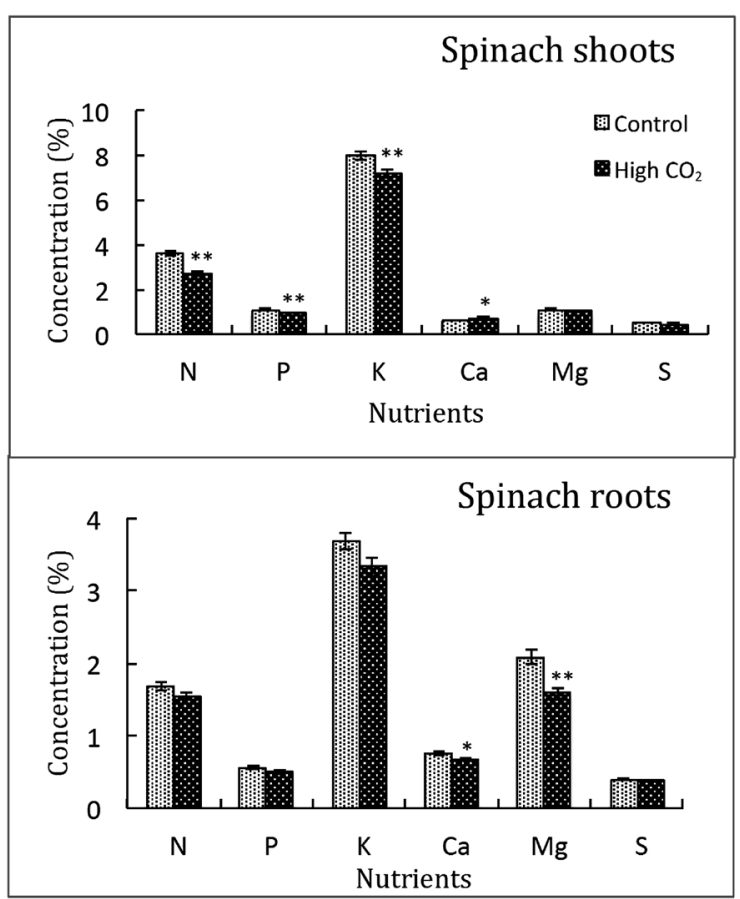

Figure 3. Nutrient concentration in spinach at ambient and elevated $\left[\mathrm{CO}_{2}\right]$. Spinach plants were grown at ambient and elevated level of $\mathrm{CO}_{2}$. Levels of major nutrients in shoots and roots were measured in the shoots and roots after harvest. Means with standard error bars and significant differences at $p<0.05\left(^{*}\right)$ and $p<0.01\left(^{* *}\right)$ are presented.

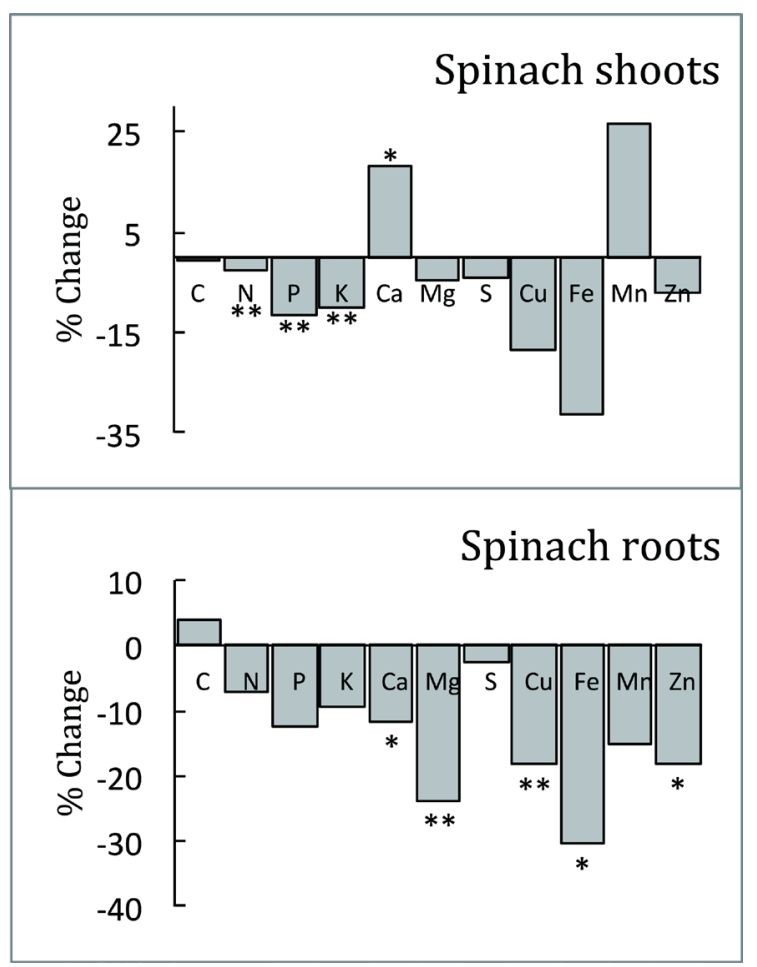

Figure 4. Percent change in nutrient concentrations in spinach in response to elevated $\left[\mathrm{CO}_{2}\right]$. The changes in the nutrient concentration relative to the controls in shoots and roots of spinach caused by elevated $\left[\mathrm{CO}_{2}\right]$ are presented. Significant differences are indicated at $p<0.05\left(^{*}\right)$ and $p<0.01\left(^{* *}\right)$. 
At elevated $\left[\mathrm{CO}_{2}\right]$, the decline in the accumulation of protein, zinc and iron in many $\mathrm{C}_{3}$ crops can cause serious problems to a large portion of global population which depends on these crops to meet the dietary requirements of these nutrients [18]. We found that zinc concentration was suppressed by nearly $30 \%$ in lettuce shoots and potassium level reduced significantly both in lettuce and spinach shoots by elevated $\left[\mathrm{CO}_{2}\right]$. Zinc deficiency is globally a common problem especially in sub-Saharan Africa and South Asia, about $17.3 \%$ of global population is at risk of being afflicted by this problem [30]. Potassium is another nutrient that is likely to be deficient in human diet and is an important electrolyte in human body and plays a vital role in muscle function, hydration and in regulating blood pressure [32]. The concentration of sulfur, a vital nutrient involved in many cellular oxidation-reduction reactions and in the formation collagen, a protein found in connective tissues, was also reduced by more than $37 \%$ in lettuce shoots. Considering that most of the global population depends on a few restricted number of staple crops to meet its nutritional requirement, poor nutrient content in these crops is likely to be a major concern as it can lead to a wide spread global health problems [18] [33].

A similar trend of depressed nutrient concentrations with regard to both macro and micro nutrients was observed in roots of these crops as well. At elevated $\left[\mathrm{CO}_{2}\right]$, nitrogen concentration was significantly decreased in lettuce roots, while levels of a number of nutrients including calcium, magnesium, copper, iron and zinc were lower in spinach roots.

It is interesting to note that the concentration of all the major plant nutrients (nitrogen, phosphorus and potassium) was much higher in the shoots than in the roots of both crops at ambient and elevated $\mathrm{CO}_{2}$ levels, indicating they are highly mobile within the plants, and shoots tend to accumulate these nutrients preferentially. Potassium is known to be highly mobile within the plants, and thus, both lettuce and spinach shoots had the highest concentration of this among all other mineral nutrients. This is consistent with the observation that plants tend to take up potassium in excess of what is actually needed for their growth, known as luxury consumption [34]. Also, spinach shoots had a higher concentration of zinc, three times of that observed in the roots, although zinc is not known to be a highly mobile nutrient (Table 1). In contrast, as iron is relatively immobile nutrient, very little of what was taken up by the roots was translocated to the shoots, as indicated by its very high concentration in roots both in lettuce and spinach and only less than $2.5 \%$ of what was taken up by the roots was present in the shoots.

In lettuce leaves, the total phenolic content and the total antioxidant capacity were much higher at elevated $\left[\mathrm{CO}_{2}\right]$ (Figure 5). Compared to plants grown at ambient $\left[\mathrm{CO}_{2}\right]$, the total phenolic content and the total antioxidant capacity in the leaves increased by about $63 \%$ and $49 \%$ respectively at elevated $\left[\mathrm{CO}_{2}\right]$. However, in contrast, there was no significant difference in either the total phenolic content or the total antioxidant capacity

Table 1. The mineral nutrient concentrations of shoots and roots of lettuce and spinach grown at ambient and elevated $\left[\mathrm{CO}_{2}\right]$. Means with standard errors and significant differences at $\mathrm{p}<0.05\left(^{*}\right)$ and $\mathrm{p}<0.01\left(^{* *}\right)$ are presented.

\begin{tabular}{|c|c|c|c|c|}
\hline \multirow[b]{3}{*}{ Lettuce } & \multicolumn{4}{|c|}{ Concentration (ppm) } \\
\hline & \multicolumn{2}{|c|}{ Shoot } & \multicolumn{2}{|c|}{ Root } \\
\hline & Control & High $\left[\mathrm{CO}_{2}\right]$ & Control & High $\left[\mathrm{CO}_{2}\right]$ \\
\hline $\mathrm{Cu}$ & $6.06 \pm 0.32$ & $4.75 \pm 40^{*}$ & $16.73 \pm 1.12$ & $13.49 \pm 1.83$ \\
\hline $\mathrm{Fe}$ & $108.01 \pm 8.43$ & $94.30 \pm 5.18$ & $6696.95 \pm 546.96$ & $5380.26 \pm 1326.43$ \\
\hline $\mathrm{Mn}$ & $168.702 \pm 1.46$ & $115.59 \pm 8.51$ & $176.97 \pm 16.40$ & $149.77 \pm 21.24$ \\
\hline $\mathrm{Zn}$ & $42.19 \pm 2.03$ & $29.78 \pm 0.89^{* *}$ & $32.37 \pm 1.075$ & $27.92 \pm 3.30$ \\
\hline \multicolumn{5}{|l|}{ Spinach } \\
\hline $\mathrm{Cu}$ & $12.721 \pm 0.85$ & $10.38 \pm 0.90$ & $24.08 \pm 0.81$ & $19.68 \pm 0.31^{* *}$ \\
\hline $\mathrm{Fe}$ & $161.07 \pm 33.39$ & $110.63 \pm 5.80$ & $7273.68 \pm 598.60$ & $5057.65 \pm 442.67^{*}$ \\
\hline $\mathrm{Mn}$ & $146.14 \pm 12.57$ & $184.57 \pm 19.80$ & $201.65 \pm 14.93$ & $171.46 \pm 9.15$ \\
\hline $\mathrm{Zn}$ & $219.88 \pm 11.56$ & $203.76 \pm 90$ & $68.55 \pm 4.25$ & $56.00 \pm 3.37^{*}$ \\
\hline
\end{tabular}




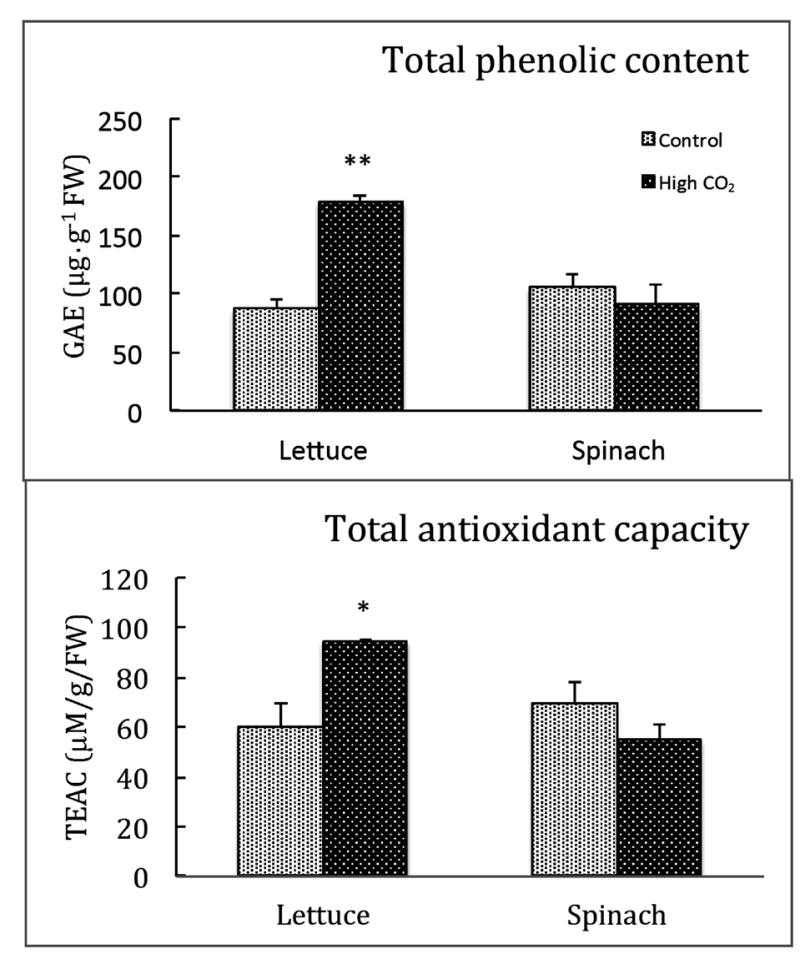

\begin{abstract}
Figure 5. Total phenolic content and total antioxidant capacity in lettuce and spinach at ambient and elevated $\left[\mathrm{CO}_{2}\right]$. The total phenolic content (as gallic acid equivalent) and total antioxidant capacity (as trolox equivalent) were determined after harvest in lettuce and spinach shoots from plants grown at ambient and elevated $\left[\mathrm{CO}_{2}\right]$. Means with standard error bars and significant differences at $p<0.05\left(^{*}\right)$ and $p<0.01\left(^{* *}\right)$ are presented.
\end{abstract}

between spinach plants grown at ambient and elevated $\mathrm{CO}_{2}$ levels (Figure 5). The higher total phenolics in lettuce was also noted by Perez-Lopez et al. [35] in two lettuce cultivars along with total glutathione and carotenoids content at elevated CO2 level. Similarly, Zhang et al. [23] showed that elevated $\left[\mathrm{CO}_{2}\right]$ could improve health-promoting and sensory qualities of tomato fruits grown in greenhouse. High $\left[\mathrm{CO}_{2}\right]$ favors increased photosynthetic activity in many plant species favoring higher $\mathrm{C}-\mathrm{N}$ ratio which can have a positive impact on the carbon based phytochemicals such as phenolic compounds and their derivatives in plants. Wu et al. [21] found that elevated $\left[\mathrm{CO}_{2}\right]$ increased the $\mathrm{C}-\mathrm{N}$ ratio in leaves of cotton plants along with tannins and gossypol, a phenolic aldehyde commonly found in cotton plants.

In addition to the nutritional quality of these crops, we also examined their plant growth characteristics at ambient and elevated $\mathrm{CO}_{2}$ conditions. At elevated $\left[\mathrm{CO}_{2}\right]$, there was significant increase in the dry biomass accumulation in lettuce, more than $18 \%$ over the ambient $\mathrm{CO}_{2}$ level (Figure 6). Similar results have been observed in lettuce especially with shoot biomass [36] but the results are variable depending on the cultivar [35]. Although lettuce plants grown at elevated $\left[\mathrm{CO}_{2}\right]$ increased their biomass, their overall leaf area decreased with much greener and thicker leaves compared to their counterparts grown at ambient $\left[\mathrm{CO}_{2}\right]$. Both shoot and root biomass in lettuce increased at high $\left[\mathrm{CO}_{2}\right]$, however, the root growth appeared to be relatively higher than the shoot growth at elevated $\left[\mathrm{CO}_{2}\right]$ resulting in lower shoot-root biomass ratio (data not shown). At elevated $\left[\mathrm{CO}_{2}\right]$, although there was no difference in biomass, there was a significant decrease in leaf area in spinach between these two growing conditions, just as in lettuce plants. Also, no significant difference in plant height and leaf number either in lettuce or spinach was observed (data not presented).

The net photosynthetic rate of young lettuce plants (at 2-week stage) was much higher, more than 2-fold at elevated $\left[\mathrm{CO}_{2}\right]$, than at ambient $\left[\mathrm{CO}_{2}\right]$ (Figure 7). However, with longer exposure (for 3 weeks) to high $\left[\mathrm{CO}_{2}\right]$, the net photosynthetic rate declined well below the control plants (at ambient $\left[\mathrm{CO}_{2}\right]$ ). Similar observations have been made in a number of plant species wherein long term exposures to higher $\left[\mathrm{CO}_{2}\right]$ resulted in attenuation of the typical positive response of growth and photosynthesis as the plants acclimate to the elevated levels [6] [8] 


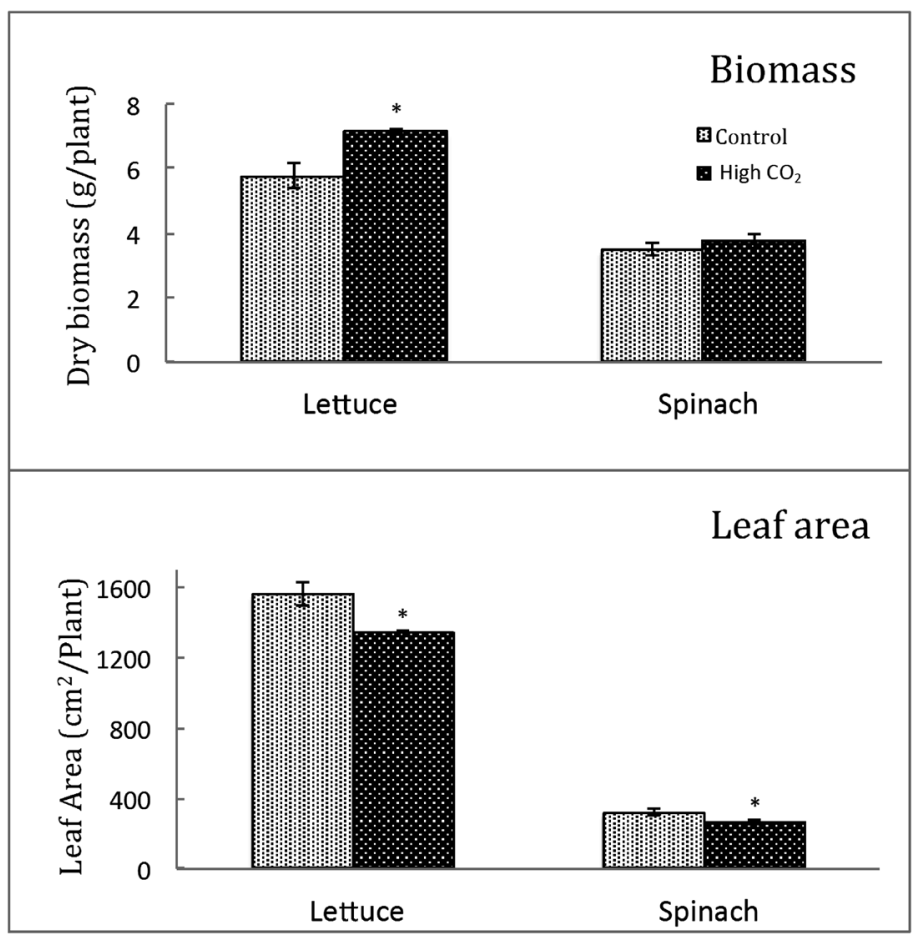

Figure 6. Biomass accumulation and leaf area in lettuce and spinach at ambient and elevated $\left[\mathrm{CO}_{2}\right]$. Biomass (dry weight basis) and leaf area of individual plants of lettuce and spinach were determined after harvest. Means with standard error bars and significant differences at $p$ $<0.05\left(^{*}\right)$ are presented.

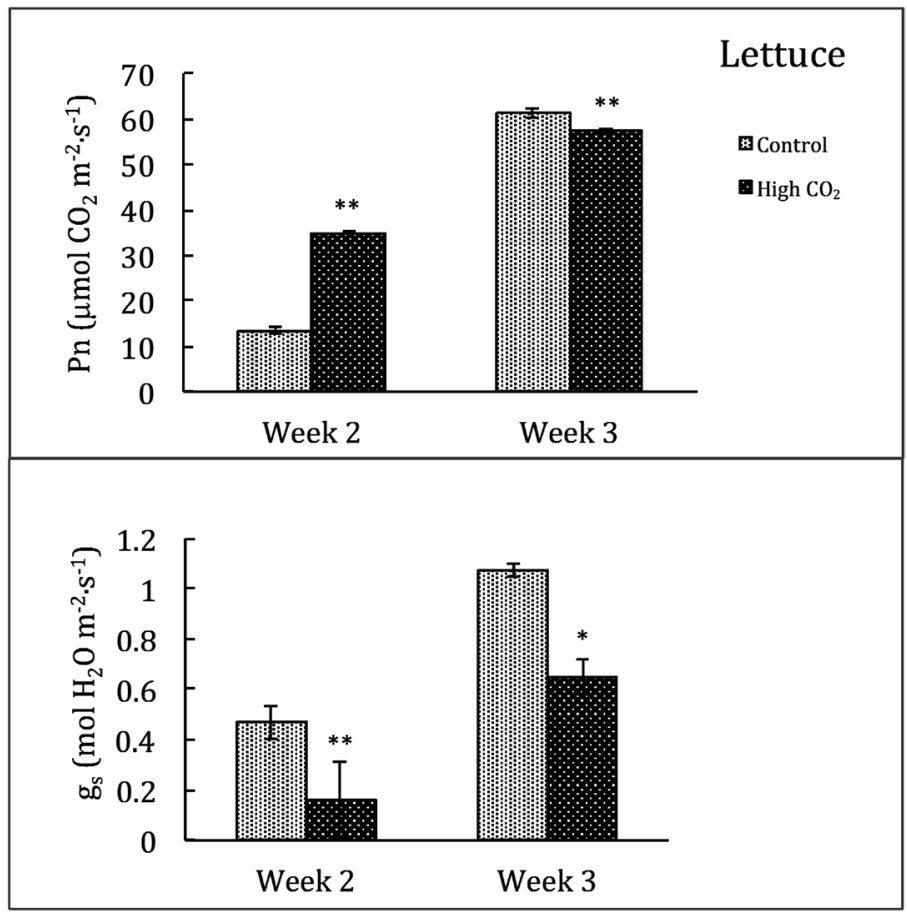

Figure 7. Photosynthetic activity and stomatal conductance in lettuce at ambient and elevated $\left[\mathrm{CO}_{2}\right]$. The net photosynthesis $(\mathrm{Pn})$ and stomatal conductance $\left(g_{\mathrm{s}}\right)$ were measured on fully expanded leaves after 2 and 3 weeks of treating plants with elevated $\left[\mathrm{CO}_{2}\right]$. Means with standard error bars and significant differences at $p<0.05\left(^{*}\right)$ and $p<0.01\left(^{* *}\right)$ are presented. 
[30] [37]-[39]. Similarly, a study aimed at examining the partition of carbon in oak seedlings at elevated $\left[\mathrm{CO}_{2}\right]$ showed that the dry matter accumulation was higher in the beginning of the season but drastically decreased as reflected by the decrease in the photosynthetic activity toward the end of the season [40]. The decline in photosynthetic activity over the long term appears to be due to a decrease in nitrogen content and the amount of $\mathrm{CO}_{2}$ fixing enzyme, Rubisco, in the leaves. In actively growing leaves, Rubisco is a major nitrogen containing compound in the leaves and is often the rate limiting enzyme in carbon assimilation. As elevated $\mathrm{CO}_{2}$ levels suppress nitrogen assimilation in plants, long term exposure exposure of plants to elevated $\left[\mathrm{CO}_{2}\right]$ results in reducing the Rubisco content and its efficiency in fixing $\mathrm{CO}_{2}$ [8] [41]. Similar to older lettuce plants, photosynthetic efficiency of spinach plants was not affected by elevated [CO2] (Figure 8). In addition, leaf total chlorophyll content both in lettuce and spinach was not affected by higher $\left[\mathrm{CO}_{2}\right]$ (Table 2). Although some studies have shown a decrease in chlorophyll content in lettuce at elevated $\left[\mathrm{CO}_{2}\right]$ [36] the results seem quite variable [35].

Elevated $\left[\mathrm{CO}_{2}\right]$ reduced the stomatal conductance by nearly $60 \%$ and $65 \%$ in lettuce and spinach, respectively (at 3 week stage) compared to ambient $\left[\mathrm{CO}_{2}\right]$ (Figure 7 and Figure 8). This is consistent with previous studies which show that elevated $\left[\mathrm{CO}_{2}\right]$ increases water use efficiency of plants by reducing stomatal conductance and transpiration rates in several plant species [6] [36] [38] [42]. This is likely to have an impact not only on water

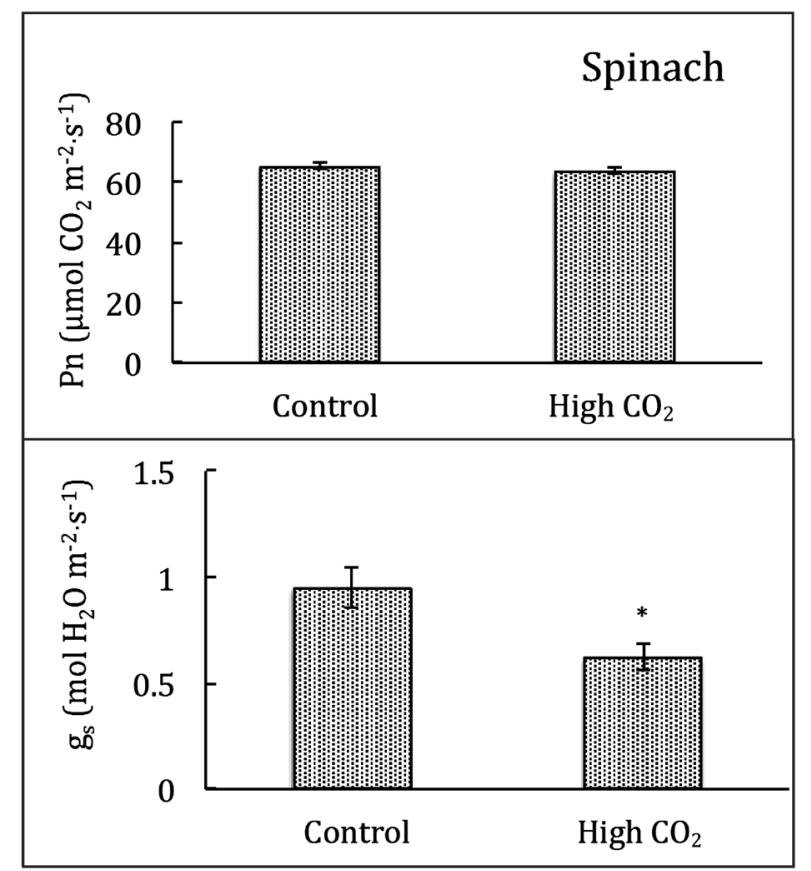

Figure 8. Photosynthetic activity and stomatal conductance in spinach at ambient and elevated $\left[\mathrm{CO}_{2}\right]$. The net photosynthesis $(\mathrm{Pn})$ and stomatal conductance $\left(\mathrm{g}_{\mathrm{s}}\right)$ were measured on fully expanded leaves after 3 weeks of treating plants with elevated $\left[\mathrm{CO}_{2}\right]$. Means with standard error bars and significant differences at $p<0.05\left(^{*}\right)$ are presented.

Table 2. Leaf chlorophyll content of lettuce and spinach plants grown at ambient and elevated $\left[\mathrm{CO}_{2}\right]$ determined at the time of harvest and expressed as mg/g FW. Means with standard errors are presented.

\begin{tabular}{|c|c|c|c|}
\hline & Chl a & $C h l b$ & Total Chl \\
\hline \multicolumn{4}{|l|}{ Lettuce } \\
\hline Control & $7.17 \pm 2.04$ & $17.61 \pm 1.29$ & $109 \pm 4.14$ \\
\hline High $\left[\mathrm{CO}_{2}\right]$ & $6.56 \pm 0.47$ & $27.77 \pm 6.32$ & $136 \pm 14.00$ \\
\hline \multicolumn{4}{|l|}{ Spinach } \\
\hline Control & $4.76 \pm 0.54$ & $17.57 \pm 0.68$ & $82.89 \pm 3.26$ \\
\hline High $\left[\mathrm{CO}_{2}\right]$ & $4.11 \pm 0.61$ & $17.74 \pm 2.48$ & $80.07 \pm 11.42$ \\
\hline
\end{tabular}


status but also on the photosynthetic activity of these plants. Thus, one of the contributing factor for the decreased photosynthetic rate observed in lettuce plants at higher $\left[\mathrm{CO}_{2}\right]$ may be their reduced stomatal conductance and leaf area, which could affect not only water loss from the plants but also the influx of $\mathrm{CO}_{2}$ into the leaves.

\section{Conclusion}

Rising atmospheric $\mathrm{CO}_{2}$ levels can have a negative impact on the nutritional quality of lettuce and spinach, two commonly consumed leafy vegetables. Elevated $\left[\mathrm{CO}_{2}\right]$ depresses the concentration of a number of nutrients which are important for human nutrition in the edible parts of these plants. It decreases the concentration of nitrogen (protein), phosphorus and potassium along with many important micronutrients including copper, zinc, magnesium and sulfur in either lettuce, spinach or both. The significant decline in nutritional quality in leafy vegetables at high $\left[\mathrm{CO}_{2}\right]$ may portend a potential for a wide-spread dietary nutrient deficiency especially as fruits and vegetables are becoming a major part of our daily diet. However in response to high $\left[\mathrm{CO}_{2}\right]$, the total phenolic content and antioxidant capacity which are linked to health-promoting qualities increase in lettuce but not in spinach. At elevated $\left[\mathrm{CO}_{2}\right]$. Thus, there is a decrease in stomatal conductance and leaf area with no effect on carbon accumulation. The results indicate that rising $\mathrm{CO}_{2}$ levels can compromise the general nutritional quality by depressing the concentration of many essential nutrients in commonly consumed leafy vegetables such as lettuce and spinach.

\section{References}

[1] Intergovernmental Panel on Climate Change (IPCC) (2013) Summary for Policy Makers. Climate Change 2013: The Physical Science Basis. Contribution of Working Group I to the 5th Assessment Report of the Intergovernmental Panel on Climate Change, Cambridge University Press. Cambridge and New York.

[2] Tauz, M., Tauz-Posch, S., Norton, R.M., Fitzgerald, G.J., Nicolas, M.E. and Seneweera, S. (2013) Understanding Crop Physiology to Select Breeding Targets and Improve Crop Management under Increasing Atmospheric $\mathrm{CO}_{2}$ Concentrations. Environmental and Experimental Botany, 88, 71-80. http://dx.doi.org/10.1016/j.envexpbot.2011.12.005

[3] Zhang, G., Sakai, H., Usui, Y., Tokida, T., Nakamura, H., Zhu, C., Fukoka, M., Kobayashi, K. and Hasegawa, T. (2015) Grain Growth of Different Rice Cultivars under Elevated $\mathrm{CO}_{2}$ Concentrations Affects Yield and Quality. Fields Crop Research, 179, 72-80. http://dx.doi.org/10.1016/j.fcr.2015.04.006

[4] Ainsworth, E.A., Davey, P.A., Bernachi, C.J., Dermody, O.C., Heaton, E.A., Moore, D.J., Morgan, P.B., Naidu, S.L., Yoo Ra, H.S., Zhu, X.G., Curtis, P.S. and Long, S.P. (2002) A Meta-Analysis of Elevated $\left[\mathrm{CO}_{2}\right]$ Effects on Soybean (Glycine max) Physiology, Growth and Yield. Global Change Biology, 8, 695-709. http://dx.doi.org/10.1046/j.1365-2486.2002.00498.x

[5] Azam, A., Khan, I., Mahmood, A. and Hameed, A. (2013) Yield, Chemical Composition and Nutritional Quality Responses of Carrot, Radish and Turnip to Elevated Atmospheric Carbon Dioxide. Journal of the Science of Food Agriculture, 93, 3237-3244. http://dx.doi.org/10.1002/jsfa.6165

[6] Prior, S.A., Runion, G.B., Marble, S.C., Rogers, H.H., Gilliam, C.H. and Torbert, H.A. (2011) A Review of Elevated Atmospheric $\mathrm{CO}_{2}$ Effects on Plant Growth and Water Relations: Implications for Horticulture. HortScience, 46, 158 162.

[7] Kimball, B.A. (1983) Carbon Dioxide and Agricultural Yield: An Assemblage and Analysis of 430 Prior Observations. Agronomy Journal, 75, 779-788. http://dx.doi.org/10.2134/agronj1983.00021962007500050014x

[8] Ainsworth, E.A. and Long, S.P. (2005) What Have We Learned from 15 Years of Free-Air $\mathrm{CO}_{2}$ Enrichment (FACE)? A Meta-Analytic Review of the Responses of Photosynthesis, Canopy Properties and Plant Production to Rising $\mathrm{CO}_{2}$. New Phytology, 165, 351-372. http://dx.doi.org/10.1111/j.1469-8137.2004.01224.X

[9] Kant, S., Seneweera, S., Rodin, J., Mateme, M., Burch, D., Rothstein, S.J. and Spangenberg, G. (2012) Improving Yield Potential in Crops under Elevated $\mathrm{CO}_{2}$ : Integrating the Photosynthetic and Nitrogen Utilization. Frontiers in Plant Science, 3, 1-9.

[10] Radoglou, K.M., Aphalo, P. and Jarvis, P.G. (1992) Response of Photosynthesis, Stomatal Conductance and Water Use Efficiency to Elevated $\mathrm{CO}_{2}$ and Nutrient Supply to Acclimated Seedlings of Phaseolus vulagaris L. Annals of Botany, 70, 257-264.

[11] Mortensen, L.M. (1987) $\mathrm{CO}_{2}$ Enrichment in Greenhouses. Crop Responses. Scientia Horticulultae, 33, 1-25. http://dx.doi.org/10.1016/0304-4238(87)90028-8

[12] USDA-NAL (2015) Fruits \& Veggies-More Matters. 
https://fnic.nal.usda.gov/dietary-guidance/fruits-veggies-more-matters-resources/fruits-veggies-more-matters

[13] GAO (2002) Fruits and Vegetables: Enhanced Federal Efforts to Increase Consumption Could Yield Health Benefits for Americans. GAO-02-657.

[14] Kalt, W. (2005) Effects of Production and Processing Factors on Major Fruit and Vegetable Antioxidants. Journal of Food Science, 70, R11-R19. http://dx.doi.org/10.1111/j.1365-2621.2005.tb09053.x

[15] Rajashekar, C.B., Carey, E.E., Zhao, X. and Oh, M.M. (2009) Health-Promoting Phytochemicals in Fruits and Vegetables: Impact of Abiotic Stresses and Crop Production Practices. Functional Plant Science and Biotechnology, 3, 30-38.

[16] Ziska, L.H., Bunce, J.A., Shimono, H., Gealy, D.R., Baker, J.T., Newton, P.C., Reynolds, M.P., Jagadish, K.S., Zhu, C., Howden, M. and Wilson, L.T. (2012) Food Security and Climate Change: On the Potential to Adapt Global Crop Production by Active Selection to Rising Carbon Dioxide. Proceedings of Royal Society of London Series B, 279, 4097-4105. http://dx.doi.org/10.1098/rspb.2012.1005

[17] Amthor, J.S. (2001) Effects of Atmospheric $\mathrm{CO}_{2}$ on Wheat Yield: Review of Results from Experiments Using Various Approaches to Control $\mathrm{CO}_{2}$ Concentration. Field Crops Research, 73, 1-34. http://dx.doi.org/10.1016/S0378-4290(01)00179-4

[18] Myers, S.S., Zanobetti, A., Kloog, I., Huybers, P., Leakey, A.D.B., Bloom., A.J., Carlisle, E., Dietterich, L.H., Fitzgerald, G., Hasegawa, T., Holbrook, M., Nelson, R., Ottman, M.J., Raboy, V., Sakai, H., Sartor, K., Schwartz, J., Seneweera, S., Tausz, M. and Usui, Y. (2014) Increasing $\mathrm{CO}_{2}$ Threatens Human Nutrition. Nature, 510, 139-142. http://dx.doi.org/10.1038/nature13179

[19] Loladze, I. (2014) Hidden Shift of the Ionome of Plants Exposed to Elevated $\mathrm{CO}_{2}$ Depletes Minerals at the Base of Human Nutrition. eLife, 3, e02245. http://dx.doi.org/10.7554/eLife.02245

[20] Oh, M.M., Carey, E.E. and Rajashekar, C.B. (2009) Environmental Stresses Induce Health-Promoting Phytochemicals in Lettuce. Plant Physiology and Biochemistry, 47, 578-583. http://dx.doi.org/10.1016/j.plaphy.2009.02.008

[21] Wu, G., Chen, F., Xiao, N. and Ge, F. (2011) Influences of Elevated $\mathrm{CO}_{2}$ and Pest Damage on the Allocation of Plant Defense Compounds in Bt-Transgenic Cotton and Enzymatic Activity of Cotton Aphid. Insect Science, 18, 410-408. http://dx.doi.org/10.1111/j.1744-7917.2011.01429.x

[22] Trumble, J.T. and Butler, C.D. (2009) Climate Change Will Exacerbate California’s Insect Problems. California Agriculture, 63, 73-78. http://dx.doi.org/10.3733/ca.v063n02p73

[23] Zhang, Z., Liu, L., Zhang, M., Zhang, Y. and Wang, Q. (2014) Effect of Carbon Dioxide Enrichment on Health-Promoting Compounds and Organoleptic Properties of Tomato Fruits Grown in Greenhouse. Food Chemistry, 153, 157-163. http://dx.doi.org/10.1016/j.foodchem.2013.12.052

[24] Gieseking, J.E., Snider, H.J. and Getz, C.A. (1935) Destruction of Organic Matter in Plant Material by the Use of Nitric and Perchloric Acids. Industrial and Engineering Chemistry-Analytical Edition, 7, 185-186. http://dx.doi.org/10.1021/ac50095a021

[25] Miller, N.J. and Ric-Evans, C.A. (1996) Spectrophotometric Determination of Antioxidant Activity. Redox Report, 2, 161-171.

[26] Pennycooke, J.C., Cox, S. and Stushnoff, C. (2005) Relationship of Cold Acclimation, Total Phenolic Content and Antioxidant Capacity with Chilling Tolerance in Petunia (Petunia x Hybrid). Environmental Experimental Botany, 53, 225-232. http://dx.doi.org/10.1016/j.envexpbot.2004.04.002

[27] Pooter, H. and Jong-Van Berkel, Y.D. (2011) Chlorophyll Extraction and Determination. http://prometheuswiki.publish.csiro.au/tiki-index.php?page=Chlorophyll+extraction+and+determination

[28] Muller, O. and Krawinkel, M. (2005) Malnutrition and Health in Developing Countries. Canadian Medical Association Journal, 173, 279-286. http://dx.doi.org/10.1503/cmaj.050342

[29] Wessells, K.R. and Brown, K.H. (2012) Estimating the Global Prevalence of Zinc Deficiency: Based on Zinc Availability in National Food Supplies and the Prevalence of Stunting. PLoS ONE, 7(11), e50568. http://dx.doi.org/10.1371/journal.pone.0050568

[30] Bloom, A.J., Asensio, J.S.R., Randall, L., Rachmilevitch, S., Cousins, A.B. and Carlisle, E.A. (2012) $\mathrm{CO}_{2}$ Enrichment Inhibits Shoot Nitrate Assimilation in $\mathrm{C}_{3}$ but Not $\mathrm{C}_{4}$ Plants and Shows Growth under Nitrate in $\mathrm{C}_{3}$ Plants. Ecology, 93, 355-367. http://dx.doi.org/10.1890/11-0485.1

[31] Taub, D.R. and Wang, X. (2008) Why Are Nitrogen Concentrations in Plant Tissues Lower under Elevated $\mathrm{CO}_{2}$ ? A Critical Examination of the Hypotheses. Journal of Integrative Plant Biology, 50, 1365-1374. http://dx.doi.org/10.1111/j.1744-7909.2008.00754.x

[32] WHO (2012) Guideline: Potassium Intake for Adults and Children. World Health Organization, Geneva, 42.

[33] Black, R.E., Allen, L.H., Bhutta, Z.A., Caufield, L.E., Onis, M.D., Ezzati, M., Mathers, C. and Rivera, J. (2008) Maternal and Child Undernutrition: Global and Regional Exposures and Health Consequences. Lancet, 371, $243-260$. 
[34] Bartholomew, R.P. and Janssen, G. (1929) Luxury Consumption of Potassium by Plants and Its Significance. Agronomy Journal, 21, 751-765. http://dx.doi.org/10.2134/agronj1929.00021962002100070005x

[35] Perez-Lopez, U., Miranda-Apodaca, J., Munoz-Rueda, A. and Mena-Petite, A. (2015) Interacting Effects of High Light and Elevated $\mathrm{CO}_{2}$ on the Nutraceutical Quality of Two Differently Pigmented Lactuca sativa Cultivars (Blonde of PARIS Batavia and Oak Leaf). Scientia Horticulturae, 191, 38-48. http://dx.doi.org/10.1016/j.scienta.2015.04.030

[36] Baslam, M., Garmendia, I. and Goicoechea, N. (2012) Elevated $\mathrm{CO}_{2}$ May Impair the Beneficial Effect of Arbuscular Mycorrhizai Fungi on the Mineral and Phytochemical Quality of Lettuce. Annals of Applied Ecology, 161, 180-191.

[37] Long, S.P., Ainsworth, E.A., Rogers, A. and Ort, D.R. (2004) Rising Atmospheric Carbon Dioxide: Plants Face the Future. Annual Review of Plant Biology, 55, 593-609. http://dx.doi.org/10.1146/annurev.arplant.55.031903.141610

[38] Drake, B.G., Gonzales-Meler, M.A. and Long, S.P. (1997) More Efficient Plants: A Consequence of Rising Atmospheric $\mathrm{CO}_{2}$. Annual Review of Plant Physiology and Plant Molecular Biology, 48, 609-639. http://dx.doi.org/10.1146/annurev.arplant.48.1.609

[39] Lindhout, P. and Pet, G. (1990) Effects of $\mathrm{CO}_{2}$ Enrichment on Young Plant Growth of 96 Genotypes of Tomato (Lycopersicon esculentum). Euphytica, 51, 191-196.

[40] Vivin, P., Gross, P., Aussenac, G. and Guehl, J.M. (1995) Whole-Plant $\mathrm{CO}_{2}$ Exchange, Carbon Partitioning and Growth in Quercus robur Seedlings Exposed to Elevated $\mathrm{CO}_{2}$. Plant Physiology and Biochemistry, 33, $201-211$.

[41] Moore, B.D., Cheng, S.H., Rice, J. and Seemann, J.R. (1998) The Biochemical and Molecular Basis for Photosynthetic Acclimation to Elevated Atmospheric $\mathrm{CO}_{2}$. Plant Cell and Environment, 22, 567-582. http://dx.doi.org/10.1046/j.1365-3040.1999.00432.x

[42] Tremblay, A. and Gosselin, A. (1998) Effect of Carbon Dioxide Enrichment and Light. HortTechnology, 8, 524-528. 